\title{
The origins of David Rapaport's 'Portrait of Moses' story
}

\author{
RichARD RASKIN
}

DOI: https://doi.org/10.30752/nj.110168

Aвstract - David Rapaport, one of the founders of psychoanalytic ego psychology, used a story about a portrait of Moses in three of his papers in the I 950 os in order to illustrate his view that the self has the power to shape its own nature. The present article traces the origins and evolution of that story through Latin, Islamic and Jewish versions.

David Rapaport ( I 9 I I-60) was an acclaimed Hungarian-born psychologist who helped found psychoanalytic ego psychology, a Freudian school which viewed the self as fully capable of pursuing its own goals independently of instinctual drives and external constraints. In the r940s, he worked at the Menninger Clinic, eventually as chief psychologist and research director, and in the I950s, he served at the Austin Riggs Center in Massachusetts.

Keenly aware of the power of a wellwrought story to bring a point home to the reader or listener, Rapaport used a tale about Moses in three papers he had published in the r 95 os to illustrate a central principle he was helping to conceptualise. Each retelling of the story was more concise than the previous one, and the third and shortest version is undoubtedly the best:

I tried to illuminate the autonomy of the ego from the id by an old Jewish story in which Moses' portrait was brought to an Oriental king whose astrologers and phrenologists concluded from it that Moses was a cruel, greedy, craven, self-seeking man.

\begin{abstract}
The king, who had heard that Moses was a leader, kindly, generous, and bold, was puzzled, and went to visit Moses. On meeting him, he saw that the portrait was good, and said: 'My phrenologists and astrologers were wrong.' But Moses disagreed: 'Your phrenologists and astrologers were right, they saw what I was made of; what they couldn't tell you was that I struggled against all that and so became what I am.' (Rapaport I 958: I4-I 5)
\end{abstract}

In a footnote, Rapaport explains that in an earlier paper, he mistakenly described it as 'a story from the Talmud', and that he now knows it dates back to the eighteenth century and that its previous history can be found in Louis Ginzberg's Legends of the Jerws (I96r). However, the Ginzberg book provides only the briefest mention of the story's previous history, which in fact begins in GraecoRoman antiquity, as can be seen in this early version in Cicero's Tusculan Disputations $(c .45 \mathrm{BC})$ in which the two parties in play are Socrates and the physiognomist Zopyrus: 
Zopyrus, who claimed to discern every man's nature from his appearance, accused Socrates in company of a number of vices which he enumerated, and when he was ridiculed by the rest who said they failed to recognize such vices in Socrates, Socrates himself came to his rescue by saying he was naturally inclined to the vices named, but had cast them out of him by the help of reason. (King I 960: 4I 8-19)

This story, which was for centuries 'one of the most widely-cited case studies' in the field of physiognomy (McLean 2017: 66), was viewed by some as suggesting that reason could overrule vices and result in good behaviour. However, there are commentators who maintain that in Cicero's version, a person's very nature is transformed by reason so that one actually becomes virtuous (Johnson and Stavru 2019: 15-16). This is an important distinction.

Continuing to evolve, the story of Zopyrus and Socrates became extremely popular in Arabic and began to include the painting of a portrait as it appears in Islamic versions in the tenth century, in which Socrates has been replaced by Hippocrates and the physiognomist is now named Polemo, known in Arabic as Aflimun:

The physiognomist Aflimun [Polemo] states in his Physiognomy that he can infer a man's character from his constitution. One day Hippocrates' pupils assembled and discussed whether they know of any contemporary more virtuous than the virtuous Hippocrates. They could name none, and somebody had the idea of testing on Hippocrates the claims advanced by Aflimun regarding physiognomy. They had a picture of Hippocrates painted and brought it to Aflimun and asked him politely to look at the individual portrayed

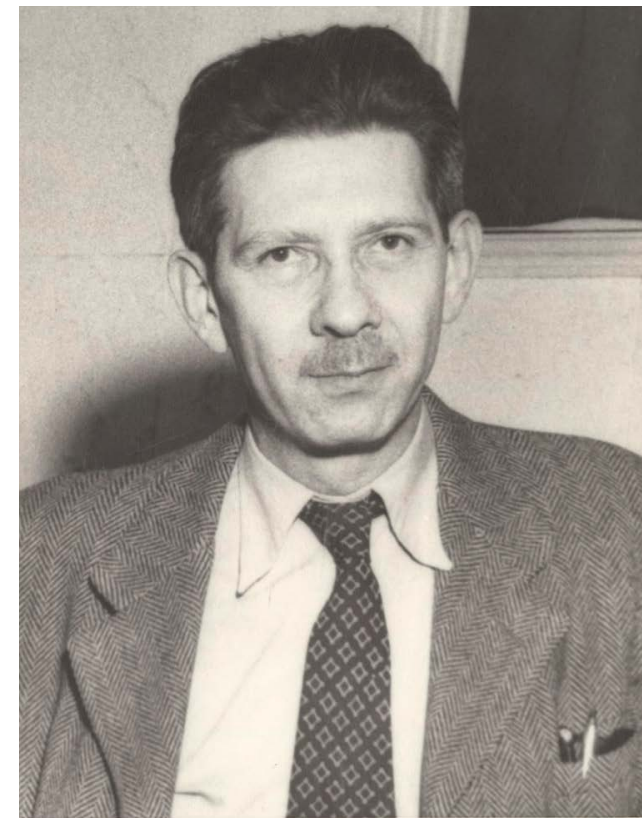

David Rapaport (1911-60). The photograph dates from 1942. Kansas Historical Society.

and deduce his character from his constitution. He looked at it, compared the individual parts of the body with one another and pronounced his verdict as follows: 'The man here loves fornication.' 'Liar,' they said, 'that is a portrait of the wise Hippocrates.' Yet Aflimun insisted that his science must be true. 'Ask him yourselves,' he said. 'That man would not agree to an untruth.' Thereupon they again went to Hippocrates and told him the story, what they had done and what Aflimun had told them. Hippocrates replied: 'Aflimun is right. I love fornication, but I control myself.' (Rosenthal I 965:254)

Perhaps as early as the thirteenth century, the story entered Jewish literature, with Aristotle holding the central role (Leiman I989: 94). But it was not until the nineteenth century that Moses finally became its main character, with no physiognomist singled out by name. It is in this form that it appears in Tiferet Yisrael, a commentary on the Mishnah 
by the Danzig Rabbi Israel Lipschutz, this specific portion being published in Vilnius in I843:

When Moses led the Israelites out of Egypt, the nations heard, they trembled, etc. (Exodus I 5 : I 4). They were particularly curious about Moses, the man through whom all these marvellous deeds had transpired. So much so, that an Arabian king sent a gifted artist to the Israelite encampment with orders to paint a portrait of the Israelite leader, and to return with it to Arabia. The artist went, painted the portrait, and brought it to the king.

The king then sent for his physiognomists, and ordered them to prepare an analysis of Moses' character, virtues, and strengths based upon his facial features as reflected in the portrait. The physiognomists complied with the king's order and reported as follows: 'If we are to render judgment solely on the basis of the facial features in the portrait, we must report, O King, that despite his distinguished reputation - he is entirely wicked, arrogant, greedy, capricious, indeed suffused with every known vice.' Upon hearing the analysis, the king was livid. 'You are sporting with me,' he cried out. 'From every corner of the globe I have heard just the opposite regarding this great man.'The physiognomists and the artist were seized with fright; they responded to the king pusillanimously, each accusing the other of incompetence. The artist claimed that the portrait was executed with precision; it was the physiognomists who had erred in their interpretation of the portrait. The physiognomists, in turn, blamed the artist, claiming that the portrait of Moses was obviously inaccurate.
The king, determined to resolve the matter, set out in his chariot on a state visit, accompanied by his troops, to the Israelite camp. Upon sighting Moses, the man of God, from the distance, he took out the portrait, gazed at it and at Moses, and knew at once that the artist's depiction had been executed with precision. The king was astounded. He entered the tent of Moses, the man of God, bowed down before him, and related the entire story to him. $\mathrm{He}$ concluded his remarks as follows: 'Before I gazed upon your face, O man of God, I suspected that the artist had been incompetent, for my physiognormists are without peer. Now that I have established that the portrait is accurate, I can only conclude that the physiognomists are at fault; they have deceived me. Their wisdom comes to naught. I have been supporting them even as they misled me with their nonsense.'

Moses, the man of God, replied: 'Not so. Indeed, the artist and the physiognomists are exceedingly competent and wise. Know that if I were naturally virtuous, I would be no more deserving of praise than is a block of wood. For it too has no human faults. I am not ashamed to admit, however, that I am naturally inclined to all the vices listed by the physiognomists, and then some. With great effort and determination, I overcame my inclinations until their very opposites became second nature to me. That is how I earned the glory that I now enjoy in heaven above and on earth below.' (Lipschutz I843 in Leiman I989: 95-6)

Lipschutz's publication of this story led decades later to serious challenges, one of which was published in Jerusalem in 1894 by a Rabbi Hayyim Isaac Aaron Rapoport (not to be confused with David Rapaport), arguing that 'Moses was righteous from birth, i.e. 
that it wasn't necessary for him to struggle with, and to overcome, his evil inclination' (Leiman 1989: 92). Another critic was the Jerusalem Rabbi Moses Joshua Leib Diskin, who wrote also in 1894 that 'the author of Tiferet Yisrael used poor judgment when he borrowed from the pagan literature of antiquity such insulting remarks about the righteous Moses' (p. 92, italics in the original). And in several editions of Tiferet Yisrael published in Israel after the mid-I95os, the story was expunged on the recommendation of Rabbi Judah Leib Fishman Maimon (p. 93).

In Hasidic circles, however, there was an acceptance of the portrait of Moses legend, where already in the late eighteenth century, Rabbi Moses Hayyim Ephrayim of Sudlykow had attributed this statement to his grandfather, the Baal Shem Tov, Rabbi Israel ben Eliezer (r698-1760), regarded as the founder of Hasidism: 'our teacher Moses was born with a natural inclination toward wickedness. Every vice was his. But he overcame his vices, transforming them into virtue' (Leiman I 989: 94). A sociological perspective is sometimes evoked in this connection, referring to 'Hasidism's outreach to common and uneducated folk in the workaday world' in contrast to the 'learned Talmudists' 'upholding the ideal of a spotlessly virtuous Moses who was immune to sinful temptations' (Segal 20I7: I3). With the Hasidic appeal to the common man in mind, and belief that everyone - including spiritual heroes - has to struggle against sinful inclinations, we can better appreciate this poignant tale attributed to Zusya of Hanipol (I7r8-i 800), an early Hasidic master:

Before his death, Rabbi Zusya said: 'In the coming world, they will not ask me: "Why were you not Moses?” They will ask me: "Why were you not Zusya?"' (Buber i96r: $25 \mathrm{I}$ )
Louis Ginzberg published his version of the portrait of Moses story in 1909 in The Legends of the Jews ( I 96 I: 294-5):

But [Moses] deserves more praise for his unusual strength of will than for his natural capacity, for he succeeded in transforming an originally evil disposition into a noble, exalted character, a change that was farther aided by his resolution, as he himself acknowledged later. After the wonderful exodus of the Israelites from Egypt, a king of Arabia sent an artist to Moses, to paint his portrait, that he might always have the likeness of the divine man before him. The painter returned with his handiwork, and the king assembled his wise men, those in particular who were conversant with the science of physiognomy. He displayed the portrait before them, and invited their judgment upon it. The unanimous opinion was that it represented a man covetous, haughty, sensual, in short, disfigured by all possible ugly traits. The king was indignant that they should pretend to be masters in physiognomy, seeing that they declared the picture of Moses, the holy, divine man, to be the picture of a villain. They defended themselves by accusing the painter in turn of not having produced a true portrait of Moses, else they would not have fallen into the erroneous judgment they had expressed. But the artist insisted that his work resembled the original closely.

Unable to decide who was right, the Arabian king went to see Moses, and he could not but admit that the portrait painted for him was a masterpiece. Moses as he beheld him in the flesh was the Moses upon the canvas. There could be no doubt but that the highly extolled knowledge of his physiognomy experts was empty twaddle. He told Moses what 
had happened, and what he thought of it. He replied: 'Thy artist and thy experts alike are masters, each in his line. If my fine qualities were a product of nature, I were no better than a log of wood, which remains forever as nature produced it at the first. Unashamed I make the confession to thee that by nature I possessed all the reprehensible traits thy wise men read in my picture and ascribed to me, perhaps to a greater degree even than they think. But I mastered my evil impulses with my strong will, and the character I acquired through severe discipline has become the opposite of the disposition with which I was born. Through this change, wrought in me by my own efforts, I have earned honor and commendation upon earth as well as in heaven.'

Both the Lipschutz and Ginzberg versions tack on a somewhat anti-climactic final swirl, referring to the honour Moses enjoys upon earth and in heaven, and this extra flourish detracts from the story's punchline, depriving the narrative of the powerful ending or closure it deserves. This is an error David Rapaport avoids in his own retellings of the story, the first two of which are as follows:

An Eastern ruler heard about the great man Moses and since he could not get Moses to visit him, nor did he have time to go to visit Moses, he sent his painter to paint this man Moses for him. When the painter returned, the king called his astrologers and phrenologists and asked them to tell him what kind of man the painting depicted. The king knew Moses by his reputation as a leader of men, as a kind man, as a great man, as a gracious man. The phrenologists and the astrologers said otherwise. To them it was the picture of a cruel, greedy, self-seeking, dishonest, haughty man. When the king heard the report he cried out, 'Either the painter does not know how to paint or there is no such science as astrology and phrenology.' So off he went to see Moses and to decide the dilemma. When he reached Moses' abode and saw the man Moses, he raised his hands and cried out, 'There is no such science as astrology and phrenology.' Moses, very puzzled by this 'how-do-you-do' asked him what he meant. When he heard the story, Moses shook his head and said to the king, 'There is such a science as astrology and phrenology. Your astrologers and phrenologists told you truly what was in me. What they could not tell you was that by fighting against it I became what I am.' (Rapaport I950: I23-4)

\section{There was an Eastern king who heard} about Moses. He heard that Moses was a leader of men, a good man, a wise man, and he wanted to meet him. But Moses, busy wandering 40 years in the desert, couldn't come. So the king sent his painters to Moses and they brought back a picture of him. The king called his phrenologists and astrologists and asked them, 'What kind of man is this?'They went into a huddle and came out with a report which read: This is a cruel, greedy, self-seeking, dishonest man. The king was puzzled. He said, 'Either my painters do not know how to paint or there is no such science as astrology or phrenology.' To decide this dilemma, he went to see Moses and after seeing him he cried out, 'There is no such science as astrology, or phrenology.'When Moses heard this he was surprised and asked the king what he meant. The king explained, but Moses only shook his head and said, 'No. Your phrenologists and astrologists are right. That's what I was made of! I fought against it and that's how I became what I am.' (Rapaport I95 I: II3) 
Explicitly citing Rapaport's use of the story, Alan Dershowitz tells it once again in 2000 , but entirely changing the focus that meant so much to Rapaport. Instead of using the tale to illustrate the ego's ability to shape itself as it wishes through an act of will, Dershowitz turns the tale into one which shows that heroes are not flawless:

Rabbinic commentators observe that 'the greater a person is, the greater is his Yetzer hara' (evil inclination), and his greatness is shown by his overcoming it. Psychologist David Rapaport related the following contemporary midrash on this topic from the life of Moses. Before being affflicted with the plagues, Pharaoh sent his royal painters to create an accurate portrait ofhis enemyto-be. He then gave the portrait to his royal phrenologists so that they could assess his strengths and weaknesses. After examining the portrait, they concluded that Moses was a weak and vain man, who would easily be intimidated and flattered - that he was no match for Pharaoh. After Moses proved that he was more than a match, Pharaoh ordered his painters and phrenologists to appear before him. 'Either the portrait was inaccurate or the interpretation was wrong,' he bellowed. When Moses next apppeared to demand the release of the Jews, Pharoah asked him to determine whether it was the painters or the phrenologists who were wrong and must die. Moses said both were correct: 'I am a weak and vain man. Those are my inherent characteristics. But I have struggled mightily to overcome them.'

The concept of the flawless biblical hero who can do no wrong and whose victims deserve their punishment is inconsistent both with real life and with the Jewish Bible. The Pentateuch, like all great literature, recognized that no human being is perfect. This recognition is one of the reasons why the Five Books of Moses have been so enduring and influential. (Dershowitz 2000: I 53-4)

This brief discussion will end where it began - with another look at David Rapaport's final retelling of the portrait of Moses' story in 'The theory of ego autonomy':

I tried to illuminate the autonomy of the ego from the id by an old Jewish story in which Moses' portrait was brought to an Oriental king whose astrologers and phrenologists concluded from it that Moses was a cruel, greedy, craven, self-seeking man. The king, who had heard that Moses was a leader, kindly, generous, and bold, was puzzled, and went to visit Moses. On meeting him, he saw that the portrait was good, and said: 'My phrenologists and astrologers were wrong.' But Moses disagreed: 'Your phrenologists and astrologers were right, they saw what I was made of; what they couldn't tell you was that I struggled against all that and so became what I am.' (Rapaport I 958: I4-I 5)

Seeing it again now, having viewed a number of other versions, should make it clear that in terms of economy of expression, power of the ending and potential to inspire, David Rapaport's final retelling of this story is unmatched as a way of helping the reader to grasp that the self is no mere product of forces beyond its control but rather a living agency empowered to overcome resistances to its shaping of its own nature and to acting as it chooses.

It is also worth noting that while the early versions of this story are largely celebrations of reason or philosophy, the Jewish versions attribute the victory of the self to an act of will. 
Richard Raskin, born in New York, has been residing in Denmark since 1972 and is now a Danish citizen. He holds both an American Ph.D. and a Danish Dr.Phil. degree. His publications on Jewish issues include Life is Like a Glass of Tea: Studies of Classic Jewish Jokes, first published by Aarhus University Press in 1992 and with an expanded second edition published in 2015 by Quid Pro Books in the USA; and A Child at Gunpoint: A Case Study in the Life of a Photo (Aarhus University Press 2004); and articles appearing in such journals as American Jewish History, Judaism: A Quarterly Journal and Rambam: Tidsskrift for jødisk kultur og forskning. A short film based on his script and entitled Seven Minutes in the Warsaw Ghetto won a number of international awards and was shown at more than 120 festivals worldwide. He recently retired as the founding editor of the peer-reviewed journal Short Film Studies, published by Intellect in the UK. He taught at Columbia University before moving to Denmark and at Aarhus University from 1972 to 2017.

\section{Bibliography}

Buber, Martin. 196r. Tales of the Hasidim: Early Masters (New York: Schocken).

Dershowitz, Alan M. 2000. The Genesis of Justice: Ten Stories of Biblical Injustice that Led to the Ten Commandments and Modern Law (New York: Warner Books).

Ginzberg, Louis. I 96 r. Legends of the Jerws, vol. 2 (New York: Simon \& Schuster).

Johnson, J. Cale, and Alessandro Stavru (eds.). 2019. Visualizing the Visible with the Human Body. Physiognomy and Ekphrasis in the Ancient World (Berlin: Gruyter).

King, J. E. I960. Cicero, Tusculan Disputations (Cambridge, MA: Harvard University Press).

Leiman, Shnayer Z. 1989. 'R. Israel Lipschutz: the portrait of Moses', Tradition: A Journal of Orthodox Thought 24(4): 9I-8.

McLean, Daniel. 20 I7. 'The Socratic Corpus: Socrates and physiognomy', in Socrates from Antiquity to the Enlightenment, ed. Michael Trapp (London: Routledge), 65-88.

Rapaport, David. r950. 'Diagnostic testing in psychiatric practice', The Bulletin (February): I I 5-25.
. I 95 I. 'The autonomy of the ego', Bulletin of the Menninger Clinic I 5(4): I I 3-23.

- I958.'The theory of ego autonomy: a generalization', Bulletin of the Menninger Clinic 22: $13^{-25}$.

Rosenthal, Franz. 1965. The Classical Heritage in Islam (London: Routledge).

Segal, Eliezer. 201 7. 'Moses's about-face', The Jewish Free Press, 7.4.201 7: I3. 